\title{
OBSERVING ISLAM WITH ETHICS: FROM HATRED THEOLOGY TO RELIGIOUS ETHICS
}

\author{
Aksin Wijaya \\ State Institute for Islamic Studies Ponorogo \\ asawijaya@yahoo.com
}

Suwendi

Syarif Hidayatullah State Islamic University Jakarta suwendi@uinjkt.ac.id

\section{Sahiron Syamsuddin}

Sunan Kalijaga State Islamic University Yogyakarta sahironsyamsuddin68@gmail.com

\begin{abstract}
The emergence of religious phenomena that lead certain Muslim groups in Indonesia to spread hatred (religious hate speech) became the primary rationale of this article. This phenomenon occurred because some Muslim groups consider their religious understanding to be the only actual theological truth while ignoring religious ethics in a religiously plural society. Therefore, some questions were raised: Firstly, what is the conceptual structure of Islam? Secondly, what does Islam teach its believers in regards to living together within the Islamic community and living among believers of other different religions? The method of ethics was employed to analyze the two research questions by describing, analyzing,
\end{abstract}


and criticizing the attitude of the Islamic movement, which spreads hatred. From this article, it is expected that Muslims should emphasize not only religious theological but also ethical truth. The findings are as follows: firstly, the conceptual structure of Islam comprises of threefold: Islam, Iman, and Ihsan, which culminate in Ihsan, Sufism, and ethics. Secondly, in regards to becoming a Muslim and embracing it among believers of other religions, Islam essentially relates its religious and theological truth to the religious ethic (the ethic of al-Qur'an), which combines three elements of ethics: God's, religious, and social ethics. The two latter ethics should always refer to God's affirmative ethics, for instance, with His Divine attributes of The Most Merciful and Just. God has mercy on human beings and treats all of them justly. Likewise, human beings essentially should do the same in relation to God and fellow human beings.

Keywords: Theology of hatred, religious ethics.

\section{A. Introduction}

This article is prompted by the emergence of religious phenomena that spread hatred (religious hate speech) and emphasize the theological truth while ignoring the religious ethics and ethics of religious plural context. This phenomenon of religious hate speech has occurred for a long time. It had become more lively since the Special Capital Region of JakartaGovernor election in 2017 when a Christian candidate, Ahok (Basuki Tjahya Purnama), and Muslim candidates, i.e., Anies Baswedan and Agus Harimurti Yudhoyono, competed for each other. Regarding this, Ahok's political opponents used religious issues to gain public sympathy and, at the same time, undermined him as an incumbent whose reputation was still ahead in various opinion polls. The resistance began 
with Ahok's accusation of being a religious blasphemer by establishing the National Movement to Safeguard the Indonesian Ulema Councils Fatwa GNPF-MUI. The GNPFMUI movement initially appeared to protest the statement of the former Governor of DKI, Ahok, who was accused of insulting Islam because he used Al-Ma'idah verses 51 within his speech in Pulau Seribu in October 2016. In this case, Ahok intended to make people not be fooled by his political opponents who often used the Al-Qur'an in political events, including in regional head elections. However, this case was used as a weapon by his political opponents to attack Ahok as a religious blasphemer. From this phenomenon, the use of religious aspects in politics unexpectedly created hatred and violence instead of ethics and peace. Religion, especially Islam, teaches ethics, preaches peace, harmony, mutual help, as well as tolerance in social life, and absolutely rejects violence except in circumstances of necessity. However, the Al-Qur'an, as the holy book of Islam, contains various meanings, so that their understanding and belief in Islam depends on their understanding of the Al-Qur'an.

This hatred theology abolishes the religious ethics and ethics of living in a religiously plural society like Indonesia. It certainly damages religious ethics because it contradicts what was taught by the Prophet Muhammad, who stated: "I was sent to refine the good character of human beings." Also, he also stated: "The best believer is the one with best character (ethic)" (Madjid, 1994). It also undermines the ethic of living in a religiously plural society because the Republic of Indonesia acknowledges the plurality of religions (Islam, Protestantism, Catholicism, Hinduism, Buddhism, 
and Confucianism) and even recognizes indigenous religions. With these two ethics, different believers can live peacefully, work together, cooperate, and support each other in the framework of The Unitary State of the Republic of Indonesia with its secular ideology of Pancasila and the plurality value as enshrined in its national slogan: Bhinneka Tunggal Ika.

State founders coined the term Republic of Indonesia (NKRI), and the one who coined the motto "Bhinneka Tunggal Ika" was Empu Tantular, a poet during the Majapahit Hindu kingdom (1293-1478) (Mpu Tantular, 2019). This motto signifies that Indonesia is a pluralistic nation in terms of race, ethnicity, class, and religion. However, a country needs not only a motto but also a nation's ideology and philosophy. According to Ismail (1999), ideology provides clarity of national identity, pride, and strength to inspire people to achieve social and political goals. It also becomes a dynamic driving force for the life of political organizations and institutions, and in the nation's life, ideology functions to unite the people in political organizations to carry out political actions objectively. The founders of this country were fully conscious of the importance of national ideology in the socio-political development of the Indonesian nation (Ismail, 1999).

After experiencing creative and innovative debates before Indonesia's independence, the state leaders finally succeeded in formulating the agreed state ideology: Pancasila (Ismail, 2003), a term that had been used long before by two famous masters who lived during the Majapahit kingdom under the leadership Hayam Wuruk, namely Empu Prapanca in his work Negarakertagama (Mpu Prapanca, 2018), and Empu Tantular in his work Sutasoma (Ismail, 2003; Mpu 
Tantular, 2019). Therefore, maintaining the integrity of the Indonesian nation and state is mandatory. One of our tasks is to avoid hatred and violent acts in the name of religion by reinterpreting the concept of Islam in the Al-Qur'an.

The following article descriptively and critically discusses religious ethics in Islam by addressing two main problems: First, what is the conceptual structure of Islam? Second, how does Islam teach its believers about religion and live together among Muslims with various sects and other religious followers? In this case, the two questions are considered interconnected. Understanding the former might affect the understanding of the latter. For instance, if the understanding of the conceptual structure of Islam tends to be exclusively theological, the ethics of religious life is usually ignored. Consequently, an ethical method was employed because the above problem is not merely theological; instead, it is mainly related to the issue of Islamic ethics about religious life and how to live together with other religious communities. It is expected from the article that Muslims should emphasize not only religious and theological but also ethical truths.

Several works about Islamic ethics are available. Some scholars discuss its key terms in the Al-Qur'an, the relationship between ethics and Islamic law, the relationship between ethics and epistemology, and the relationship between Islamic ethics and the rest of the world. Among those discussing key terms of ethics in the Al-Qur'an are Riswani (2017), Halili (2017), and Al-Khatib (2017). Meanwhile, one of the scholars who wrote about the relationship between ethics, Al-Qur'an, and Islamic law includes El Fadl (2017). In the meantime, AlAttar (2017) wrote a work about the relationship between 
ethics and epistemology in the tradition of traditional classic Islamic thought. Siddiqui (1997) wrote a work about Islamic ethics and the shift of its vital meaning. Some authors wrote Islamic ethics and its relationships with the reality of the contemporary world, such as in the politics, social life, or international relation, such as Ghafran and Yasmin (2020), Liu (2011), Khan (1997), and Chaney and Church (2017). This article focuses explicitly on religious ethics and the way Muslims live together with other religious people in Indonesia, especially the ethics towards the government, fellow human beings, and the adherents of different religions.

Human beings are creatures who act and perform things. Regarding this, human attitudes can be assessed from many perspectives, either economics, politics, culture or and especially morality and ethics. From this latest perspective, humans' attitudes can be perceived from good and bad sides. However, these two sides are not related to a specific action but personalities. For instance, the Prophet Muhammad is a good teacher but not good at teaching. This expression implies two perspectives; the first part concerns morality, whereas the second part concerns his profession as a teacher. Morally speaking, he is a good man, but not quite as a teacher. This article, therefore, discusses his moral aspect (Bertens, 2011, 2017).

There are two interrelated terms in daily lives, including morals and ethics. These terms are slightly different yet interrelated. The term 'moral' can be used in two forms: an adjective with the same meaning as ethical and a noun that refers to values or moral norms upheld by a person or particular society that governs behavior. It can be stated that moral or morality is concerned with the good or bad behaviors 
of human beings. In the meantime, the word 'ethics' refers to a noun with three interrelated meanings: 1) as values and moral norms, 2) as an ethical code, and 3) as knowledge about good and bad from a moral perspective. The last meaning essentially means a study about morality. Also, it refers to the philosophy of morality, philosophical ethics (Hariatmoko, 2003), or theory of ethics (Bertens, 2017).

Studies on the theory of ethics, according to Bertens (2011, 2017), consists of three categories; descriptive, normative, and metaethics. Descriptive ethic refers to the theory of ethics that merely describes a moral phenomenon without providing the practical judgment of goodness and badness of someone's behavior. Meanwhile, normative ethics, which is also known as philosophical ethics, attempts to locate the roots of basic values and norms and eventually raises judgment about good and bad. Metaethics, which is also known as the moral philosophy analytic camp, philosophically discusses the language context used in moral behavior, such as 'what is good, bad, just, obligatory, free, responsible, and many others' (Bertens, 2011, 2017).

These three categories of ethics theory were used to describe, interpret, and criticize the attitudes of some Islamic movements which recently commit violence and spread hatred on behalf of the religion. Therefore, the following discussion starts from a description of the conceptual structure of Islam to highlight how Islam not only relies on theological truth, let alone conveyed in full of hatred, but also the ethical truth. In this case, it was primarily founded on the latter. Later, the paper also discusses religious ethics and the way adherents of different religions coexist in Indonesia. 


\section{B. The Dimension of Ethics in Conceptual Structure}

In discussing Islam, we will cover various aspects, including its origin, term, meaning, concept, and teaching. From its origin, Islam is revealed by God, who gave the name 'Islam,' not the name by others, and it does not use the name of its messenger like other cultural or human-created religions (Al-Maududi, n.d.). Conceptually, the term Islam contains two categories of meaning: Islam as an attitude of total submission to God, and Islam as a proper name which is a manifestation of submission attitude brought by each Prophet known as Sharia (Madjid, 2008; J. Rahmat, 2006). Indeed, Islam does not simply refer to a submission, but God guides it through His prophets and Holy scriptures, which is belief in God, hereafter, and good deeds (al-'amal al-saalih) (al-Baqarah:62) (Wijaya, 2019).

From the structure of its teaching, al-Quran, as the essential source of Islam, does not provide technical categorization and details about the conceptual structure of Islam. In this case, the ulama (Muslim clerics and intellectuals) and some Islamic sects make such things and provide details in many forms. The Shi'a, for instance, includes some elements into the conceptual structure of Islam, namely tawhid, nubuwwah, imamah, and iman (belief) in the day of resurrection and judgment (Al-Nafis, 2006). Mu'tazilah enumerates five elements: tawhid, al-'adl, al-wa'du wa al-wa'id, al-manzila bayna al-manzilatayn, and al-amru bi al-ma'ruf wa al-nahyi 'an al-mungkar (Al-Jabbar, n.d.). Likewise, some scholars individually make some technical categorizations and details: Islam as aqidah (creed) and sharia (regulation) by Mahmood Shaltoot, Islam as aqidah and haqiqah (knowledge) 
by Mahmud Muhammad Thaha (Thaha, 2007), "Islam consists of Islam dan Iman" by Muhammad Shahrur" (Shahrur, 1996), "Islam as aqeedah (essential) and history (accidental)" by Abd al-Karim Shoroush (Shoroush, 2009b), "Islamku, Islam Anda dan Islam Kita" ("My Islam, Your Islam, and Our Islam) by Gus Dur (Abdurrahman Wahid) (Wahid, 2006), and I classify it into "Islam Theocentric and Anthropocentric" (Wijaya, 2013).

Meanwhile, Ahl al-Sunnah wa al-Jama'ah (Sunni), the mainstream branch in Islam, creates a technical category based on a hadith narrated by Umar ibn al-Khattab, as follows:

"One day, a man appeared with exceedingly white clothes and exceedingly black hair. There were no signs of travel on him, yet we did not recognize him. He sat down in front of the Prophet, supported his knees against his, and placing his hands on his thighs. The man said, "O Muhammad, tell me about Islam." The Prophet said, "Islam is to testify there is no God but Allah and Muhammad is the Messenger of Allah, to establish prayer, to give charity, to fast the month of Ramadan, and to perform pilgrimage to the House if you are able." The man said, "You have spoken truthfully." We were surprised that he asked him and said he was truthful. He said, "Tell me about faith." The Prophet said, "Faith is to believe in Allah, His angels, His books, His messengers, The Last Day, and to believe in providence, its good and its evil." The man said, "You have spoken truthfully. Tell me about excellence." The Prophet said, "Excellence is to worship Allah as if you see Him, for if you do not see Him, He surely sees you." The man said, "Tell me about the final hour." The Prophet said, "The one asked does not know more than the one asking." The man said, "Tell me about its signs." The Prophet said, "The slave girl will give birth to her mistress, and you will see barefoot, naked, and dependent shepherds 
compete in the construction of tall buildings." Then, the man returned, and I remained. The Prophet said to me, "O Umar, do you know who the questioner was?" I said, "Allah and his messenger know best." The Prophet said, "Verily, he was Gabriel who came to teach you your religion" (Al-Shahrashtani, 1961; Muslim, 2001).

On the basis of this hadith, many Sunni ulamas categorize Prophet Muhammad's Islamic teachings into three elements; Islam, iman, and ihsan, which were later dubbed as the Islamic trilogy. Indeed, it seems that there is compartmentalization among the definition of each term as if they are separate. However, Nurcholish Madjid argues that the three concepts are interconnected and complementary. Islam (the submission to God) is meaningless or nonsensical without iman (belief), and the perfect iman will not be achieved without ihsan (performance of good deeds). Likewise, ihsan is also impossible without iman, and iman should always be accompanied by Islam. Of the three elements, ihsan is the ultimate Islamic identity of a Muslim as illustrated in al-Nahl: 90, al-Bayyinah: 5, and al-Baqarah: 178 (Azzam, n.d.; Madjid, 1994).

Sunni ulama canonizes the Islamic trilogy and provides a lengthy explanation about them, creating three Islamic knowledge: theology, Islamic jurisprudence, and Sufism. These three disciplines are indeed interrelated and complimentary, but certain groups contradict them. They insist that theology and Islamic jurisprudence are Islamic (Reda, 2019), whereas Sufism is considered a foreign influence. Moreover, certain extreme groups, like Khawaarijii-Wahhaabii (Wijaya, 2018), go further as they even say that Islamic jurisprudence 
and Sufism are considered foreign imports. These groups emphasize the dimension of iman (system belief), which is mainly tawhid (monotheism) of this trilogy, and assert it as the essence of Islam (Shahrur, 2014; Taymiyah \& AlWahhab, 1991). Muhaḥmmad ibn 'Abd al-Wahhāb, the main mastermind of this Wahabi movement group, divides the tawhid into three aspects; uluhiyah, rububiyah, as well as asma' and sifat (Taymiyah \& Al-Wahhab, 1991). Of the three elements, the uluhiyah is the most emphasized that becomes the parameter of a Muslim's religiosity (Al-Wahhab, 1969), while the other two are relegated if not ignored.

The consequence of this simplification or the reduction of Islam to this uluhiyyah is that Sufism becomes obscure under the other two disciplines. Moreover, the Sufis and philosophers who practice Sufism occasionally proposes controversial thoughts which is/are contradictory to the jurists and theologians. Furthermore, they are often accused of being unorthodox, idolaters, innovators, heretics, infidels, apostates and actors who destruct Islam.

Meanwhile, while some ulama differentiate between tasawwuf (Sufism) and Akhlaq (ethic), others consider them similar. The difference, however, is very subtle, in which Sufism is more general than ethics. Every practitioner of Sufism is ethical, but not every ethical person is practicing Sufism (Milkiyan, 2013). This is because Sufism emphasizes building spiritual relationships with God while practicing ascetic in this world. Meanwhile, ethics refers to social interaction in this world. It can be stated that Sufism is vertical as well as horizontal in nature, whereas ethics is only horizontal. It means that both are interrelated, in which ethics becomes 
part of Sufism so that the term 'ethical Sufism' emerges. AlGhazali's Ihyaa'u Uluumiddiin discusses Sufism and ethics at the same time (Quasem, 1975).

Likewise, some differentiate between Akhlaq and ethics based on their sources and methods, and some others consider them identical after identifying the contents and purpose (Zaqzuq, 1983). Ethics originates from a Greek philosophical tradition known as philosophical civilization, while Akhlaq is from Arab-Islam, a text-driven civilization (Zaqzuq, 1983). Both concepts speak about values, norms, as well as good and bad, from the perspective of personality. Because of historical processes, ethics was adopted and connected with Akhlaq thought in Islam (Bertens, 2011, 2017; Suseno, 2010) so that it became more profound and even united, as reflected in Ibn Miskawayh's work entitled Tahdzib al-Akhlaq (Aristotle, 2008; Miskawaih, 2011). However, both terms are used interchangeably by Muslim scholars. Some still use akhlaq, and others prefer ethics. Quasem (1975) wrote about alGhazali's thoughts on ethics entitled the Ethics of al-Ghazali: A Composite Ethics in Islam, while Fakhry (1996) reviewed the thoughts of Muslim scholars in his book entitled Ethical Theories in Islam.

In Indonesia, tasawwuf, akhlaaq, and ethics are studied and practiced daily only in traditional pesantren (Islamic traditional boarding schools). Some studies that are among the most extensively studied works are Ihyaa'u Uluumiddiin, al-Ta'liim wa al-Muta'alliim, Washaya al-Abaa' li al-Abnaa',', al-Akhlaq li al-Banaat, Irshaad al-'Ibaad, Nașaa'ih al-'Ibaad, and al-Adhkaar (Bruinessen, 2015). Therefore, in many pesantrens, the practices of tasawwuf, akhlaaq, and ethics are 
considered more important than theoretical understandings. Regarding this, simple living, akhlaaq, and ethics constitute the manifestation of knowledge. A well-known slogan among the community in pesantren about this is "al-'Ilmu bilaa 'Amalin, $\mathrm{ka}$ al-Shajari bilaa Thamarin," which means knowledge without application is like a tree without fruits. The application is in the form of a simple life and a practice of ethics. The pesantren students, known as santri, live a simple life in terms of food and clothing. The respect of santris toward each other, to the fellow santris, their ustadz (teachers and seniors), and kyai (the owner/grandmaster of pesantren) reflect the teaching of what they learn in Akhlaq treatises written by great ulamas. Furthermore, they do not act rudely, express hatred speeches, hoaxes, and lies in pesantren.

The opposite situation happens in the circle of Khawaarijii-Wahhaabii and Islamists who ignore tasawwuf, akhlaaq, and ethics. In this case, they commit violence, whether physical, verbal, or written, by spreading hatred, lies, provocation or agitation, slander, misogynic views, data manipulation through hoaxes, and other means. All of the acts are justified through religious proofs, for instance, some verses in the Al-Qur'an that urge killing of infidels (e.g., Q. al-Taubah: 5, dan al-Baqarah: 2) and hadith of the Prophet stating that: "I am sent to kill human until they testify there is no god but Allah and that Muhammad is the messenger of Allah, perform salaah (prayers) and pay the zakah (alms). If they do the command, their lives and properties will be saved because they have become Muslims, and of their matters belong to God" (Umar, 2019). For this reason, presenting Akhlaq and ethics as part of the Islamic trilogy becomes of the utmost importance. 


\section{Religious Ethics in Islam}

As illustrated in Al-Quran: al-Anbiya' verses 107 (see also Yaqut, 2009), it is stated that "We sent thee not save as a mercy for the peoples." On the other hand, a hadith of the Prophet says: "I was sent to this world to refine good Akhlaq (ethic)." The two statements from the two primary religious texts are interrelated in the form of causality. Regarding this, Akhlaq necessitates mercy because it is a personal quality, while mercy is a consequence of personal quality, which is actualized in behavior. Personally, the Prophet Muhammad is the reflection of noble Akhlaq qualification which the AlQur'an states as "khuluqun 'aziim", (outstandingly high standard of moral) (al-Qalam: 4) (Al-Dimasqi, n.d.), and Aishah, his beloved wife stated that the Prophet's Akhlaq is Al-Qur'an (Azzam, n.d.). Although Akhlaq qualification is embedded within his personality, the Prophet Muhammad never stopped asking God to refine his akhlaaq, and prevent him from corrupt Akhlaq (Al-Dimasqi, n.d.). During his lifetime, the Prophet Muhammad never detached Akhlaq in all aspects of his life, from private matters such as table manners, dressing and sleeping etiquette (Al-Dimasqi, n.d.) to social matters with fellow human beings, including believers of different religions, both in times of peace and war (Al-Sirjani, 2011a, 2011b; Yaqut, 2009). Since Akhlaq is highly respected in Islam, Prophet Muhammad states: "The finest believer is the one with the finest Akhlaq (ethic)" (Al-Khauli, n.d.; Madjid, 1994). Among the Qur'anic characteristics of Akhlaq include doing just, performing good deeds, keeping promises, being honest and patient (Azzam, n.d.), being humble and not arrogant (al-Furqan: 63). 
According to Izutsu (1993), there are at least three categories of Akhlaq or ethics in the Al-Qur'an, namely the ethics of God, religious, and social ethics. The last two is known as humans' ethics. God's ethics refers to the ethical characters of God, such as Most Merciful, Most Just, and many others that usually become the objects of study for sufis and theologists. With those affirmative characters, God always has His mercy on humans and treats them justly. Religious ethics refers to humans' responses toward God's ethical response in interacting with humans (Izutsu, 1993). For instance, because God always treats humans with mercy and justice, humans must respond to it by gratitude, obedience, and submission to God (Izutsu, 1993, 1997). In contrast, social ethics are social values and norms which govern human interaction. Furthermore, social ethics also reflect God's ethics. In this case, since God is always merciful and just to humans, humans should treat fellow human beings accordingly.

The three forms of Islamic ethics, according to Izutsu (1993), are interrelated. Regarding this, two human ethics, i.e. the religious ethic and social ethics, characterize God's ethics since the Islamic worldview (Al-Qur'an) is theocentric. Therefore, the two human ethics reflect God's ethics, except God's ethics, which come negatively, such as the Most Avenger. With the negative ethical character, God has the right to avenge humans who fail to praise, observe, and submit to Him. According to Hammad (2010), the avenge of God may take the form of direct punishment in this world, like what happened in the ancient community (Bani Israil), and in the hereafter against the sinful ummah of Prophet Muhammad (Hammad, 2010; Wijaya, 2018). Therefore, human ethics, either religious 
or social ethics, cannot follow or take over this type of God's ethics. Thus, humans cannot avenge fellow humans, let alone force others to submit to them (Izutsu, 1997), like what the Pharaoh did during the Prophet Moses period.

The three forms of Al-Qur'an's ethics have actually become the reference in Indonesia's religiously plural society. They might be different in many respects, but are still in one nation, Indonesia. This difference is Sunnah Allah or God's destiny because God wishes the difference among human beings. Human beings do not have the right and power to reject differences, including religious differences (Hanna, 2005). Therefore, Muslims should respect differences and ethically relate to fellow human beings, including those with different religions (Q. al-Mumtahanah: 8).

However, because of a few irresponsible Muslims who emphasize theological and exclusive truth, the political form of unitary nation, Pancasila as state ideology and plurality in Indonesia are frequently challenged. They do not only reject all of the differences but also launch terror to those who accept the secular political arrangement and its consequences. As a result, conflict is due in a matter of time. From the perspective of ethics, such problem remains in question.

Again, it lies in the way Muslims perceive the conceptual structure of Islam. As mentioned, there are differences in understanding the conceptual structure of Islam among those emphasizing the theological dimension (tawhid), while ignoring the other two dimensions (Islam and ihsan) or theology and Islamic jurisprudence. On the other hand, Sufism (ethics) groups acknowledge the harmony of the Islamic trilogy and the trilogy of Islamic knowledge. In 
my opinion, the Islamic trilogy is complementary, and the difference is a matter of their application, ,for instance, the difference between theological truth (tawhid) and tasawwuf (Akhlaq and ethics). In this case, theological truth deals with the right and wrong in mind and belief, so that it is theoretical in nature, whereas tasawwuf, akhlaaq, and ethics discuss the positive and negative aspects of someone's deeds. Thus it is theoretical and practical at the same time (Zaqzuq, 1983).

Because it is theoretical, the theological truth contains two possibilities when applied in real life. Firstly, it might be suitable for all contexts of time and space, such as the idea of monotheism, and the obligation to perform salaah (prayer). Secondly, it might only be appropriate for a particular time and space, such as the style of clothing. In this sense, ethicss is needed to convey the truth that ethics requires thinking, whether a truth is applicable in certain times and spaces. If the answer is no, a position and wise strategy in conveying the truth are necessary. Ethics in conveying truth is not always identical among Indonesians, Arabs, and Westerners. If the Arabs communicate in uncompromising and purificative language, Westerners might present it rationally. In the meantime, Indonesians do it politely and elegantly that follow the local custom.

The importance of ethics in conveying the religious theological truth can also be viewed from the concept of ethics itself. Nevertheless, there are many concepts that scholars offer, by which each concept has the same essence and purpose that is moral behavior. Some suggest that Akhlaq and ethics are preordained to be good. This ordainment law is based on the assumption that because humans are 
equipped with reason, it plays an essential role in ethical thought. It seems an unwritten law that reason knows. Thus, human preordainment becomes the fundamental norm for human behavior. As a result, humans who act in accordance with preordainment are morally good. Otherwise, an act that opposes preordainment is considered morally bad. Many aspects are related to this theory, such as the prohibition of lying. In terms of preordainment, communication between humans should be based on honesty, which is considered good because it is preordained. If there is a lie in a person's communication, however, it means they have contradicted with preordained law (Bertens, 2017).

Ethics also has an imperative categorical nature, which is a command to do good without any condition. A deed is morally good when it is performed out of obligation. In contrast, a deed is morally bad if one is doing something prohibited. This theory is not about the implication of moral action. What matters is the command to do it without any condition, which Kant (1785) calls imperative categorical. For instance, respecting others' rights is a command. In contrast, taking others' rights is against the command. Thus, an act of respecting other's rights is morally good, and this act is called an ethical and moral act. That is the opinion of 'de-ontological' ethics. Ethical or moral acts certainly provides positive things and benefits for others. Thus, each person needs to maximize the effort of providing useful things and benefits so that it belongs to the community collectively (Hazlitt, 2003). This is the moral and ethical foundation of utilitarianism. The three ethical theories can be essentially combined mainly in conveying the truth. The truth should be conveyed with ethics so that the effect of the truth does not contradict the 
preordained ethical good itself. As a result, the truth may bring benefits to the community at large (Hazlitt, 2003).

Therefore, an attitude of a group of people in a radical religious organization that often commit violent acts to convey its theological truth changes the original function of religion from guidance and mercy to spread peace to a hatred preacher which Umar (2019) coined as religious hate Speech. In addition, this attitude is against its own preordainment as an ethical creature. Furthermore, their action is considered a form of religious hypocrisy (Izutsu, 1993) because their speech and action are different compared to what is in their heart and Islamic teaching. In this case, they always use religious symbols in their speech and action, however, their hearts are filled with hatred, which is prohibited by religion. They often claim to be defenders of Islam and uphold the unity of Islam. Yet, they destroy Islam and the relationship between believers of different religions in Indonesia. They promise not to commit violence yet consistently do so because violence, hatred speech, hoax, and slander become a fundamental part of their ideology (Al-Khauli, n.d.).

\section{Coexistence Ethic among Believers of Different Religions in Indonesia}

The following discussion focuses on three forms of social ethics in social life in Indonesia: (1) ethics toward political authority; (2) ethics toward believers of different religions; and (3) ethics among Muslims. Besides showing the theoretical form of Islamic social ethics, this discussion is also expected to be a national life guide for Muslims who live in Indonesia with a principle of unity in diversity. 


\section{Ethic toward the Authority}

Politics is a high virtue because it has a good purpose: to realize prosperity for people (Aristoteles, 2004). However, because political power lures many people, sometimes people in charge forget their duties: creating policies that usher to public benefit. In this regard, citizen participation comes to play, especially intellectuals, to check and balance so that the authority works according to their duties and responsibilities.

Criticizing government is a risky business, especially if the government is an authoritarian regime. As a consequence, critics can be done fiercely and revolutionary, or elegantly. Fierce and revolutionary critique usually leads to casualties and tends to create new problems because it will be met with retaliation from the opposing sides and will make a cycle of harmful actions from both sides. An intelligent strategy should be applied in launching critique towards the authority to achieve a goal without creating new problems. This can be in the form of advice because Prophet Muhammad once said: "al-Din al-Nashihatu" (religion is advice) (Aristoteles, 2004). The second method was performed by great Muslim scholars in their time, namely Baydaba and his work, Kalilah wa Dimnah (Baydaba, 2004), and al-Ghazali with his work, al-Tibr al-Masbuuk fii Nasiihatil Muluk (Al-Ghazali, 2001). These works contain moral and philosophical advice for the authority.

Baydaba (2004) is an Indian philosopher who flourished in the $3^{\text {rd }}$ Century CE and lived under a dictatorial king of Dabsalym. People were restless about 
this and complained about him to Baydaba. The wise philosopher asked his students to give suggestions about the matter because he intended to visit the king. Fierce debates were exchanged in the meeting, especially as they imagined what would happen when the philosopher met the king. However, meeting the king was deemed the correct method to convey the critique.

As the philosopher met the king, he kept silent before the King Dabsalym allowed him to speak. This attitude represented wisdom and respect to King Dabsalym, even though the king was a tyrant. After that, the king asked the philosopher about his intention. As Baydaba expressed that people complained about the king's attitude and intended to advise the king so that he would return to be a good king, the king was furious and put the philosopher into jail. However, in the end, the king accepted the advice and asked the philosopher to assist him in fixing the situation. In addition, conveyed in an exemplary manner, ethical and morally sound, Baydaba delivered his advice using fables and animal allegory to avoid the king's fury. Since then, the king always ruled the kingdom wisely, without any casualty or hatred.

Meanwhile, al-Ghazali, an influential Muslim scholar among Sunnis, successfully criticized, downplayed, and crushed philosophers with his work Tahaafut al-Falaasifah. At the same time, he revived the religious knowledge using his another monumental work Ihyaa'u 'Uluumiddiin that was also used to launch his critique toward Muslim authorities using religious advises. The works were written in Persian and directed 
to Muhammad Ibn Malik Shah al-Shaljuk. Regarding this, allegories, tales, parables, and words of wisdom were used by great thinkers.

For instance, al-Ghazali cited Aristotle, in which he narrated a dialog of Aristotle with a person. Aristotle was asked: "Who should be called as a king besides God?" he replied: "Whomever you find him as equipped with these characters even though he is naked. They are knowledge, justice, philanthropy, humility, compassion and so forth. That person will certainly become a king because of God's protection, the light of his consciousness, his purity, his aptitude, knowledge, prioritizing public interests, respecting the ancestors and the nation generated by the ancestors to him. Therefore, they are kings and sultans" (Al-Ghazali, 2001). These words of wisdom give enlightening advice regarding the importance of those values for kings.

From those two intellectuals who were born from different civilizations, it can be concluded that criticizing an authority is not always conducted in bad-mannered and revolutionary methods, showing hatred, moreover using religion. Instead, it can be done wisely by giving a bit of lenient advice employing parables, allegories, fables like Baydaba did, or using parables, words of wisdom like al-Ghazali did. In addition, the Prophet Muhammad also suggested that religion provide advice. It is also stated in the Al-Qur'an that advice should be conveyed wisely in the most exemplary dialog. 


\section{Ethics to Adherents of other Religions}

In Indonesia, the state acknowledges six religions and some indigenous religions, though Judaism is not included. Because this article discusses the Al-Qur'an from the beginning, the following discussion presents Judaism and Christianity. The explanation of the AlQur'an about these two religions can become the analogy for adherents of different religions in Indonesia.

Judaism, Christianity, and Islam are basically originated from the same source, the God Almighty. They bring identical teachings, namely monotheism. They also acknowledge Abraham as their theological father. The trio is known internally as Abrahamic Religions or Religions of heaven. Therefore, the trio have similarities in their fundamental principles, either in aqidah (creed) or sharia (regulation). The difference between each faith lies within certain aspects of furuu'iyah (the do's and don'ts), but only a few (Husawi, 1999; Raisuni, 2010). The unified concept of the Abrahamic religions results in a unified concept of community of believers (al-Anbiya':92) (see also Donner, 2015; Madjid, 2008). For that reason, the AlQur'an takes an appreciative-critic form of relationship, either theologically or ethic-humanistically, with the adherents of Judaism and Christianity.

Firstly, theologically speaking, the Al-Qur'an accepts and respects the prophets of God before Muhammad. The Al-Qur'an acknowledges them and even mentions the names of prophets for other communities, especially the 25 prophets mentioned in the Al-Qur'an, more often than mentioning the name of Prophet Muhammad (Shoroush, 
2009a). Al-Qur'an considers the belief of those prophets and their holy scriptures as elements of the pillar of the Islamic creed (according to general understanding among Muslims) (al-Baqarah: 136). In addition to confirming stance, Al-Qur'an also positions itself as a successor (alBaqarah: 41, 91 and 97, Ali Imran: 50, al-Nisa': 47, alMaidah: 46 and 48, Fatiir: 31, al-Ahqaf: 30, and al-Saf: 6). Indeed, Al-Qur'an remains critical about the sharia of those prophets and their scriptures by accentuating its position as the "evaluator." Moreover, it also sometimes condemns the behavior of people of the book who alter some or all of the contents of the scriptures, which caused deviation from the original creed (al-Baqarah: 75, Ali Imran: 78, alNisa': 46, al-Maidah: 13, dan 41) (Summa, 2004).

Secondly, from an ethical-humanistic point of view, the Al-Qur'an requires the Prophet Muhammad to maintain a good relationship with believers of other religions (al-Mumtahanah: 8). One of the manifestations of a good relationship is da'wa (preaching to Islam) (Safi, 2011) to them wisely by giving advice and maintaining dialog with a suitable method (al-Nahl: 125) (Fatani, 2006). The Al-Qur'an suggests using appropriate words in dialogue with the opposite side, including when addressing infidels and polytheists (Saba': 24-25), in social and theological matters (Qardawi, 2004; Yaqut, 2009). Moreover, to infidels who clearly do not believe in God, the Al-Qur'an prohibits Muslims from insulting their gods because if they do so, those infidels will bite back by insulting Muslims' God (al-An'am: 108). The Al-Qur'an also commands the Prophet Muhammad and Muslims 
to say: "You shall have your religion, and I shall have my religion" (al-Kaafirun: 6) (Qardawi, 2004). Furthermore, the Prophet Muhammad is also commanded to treat them gently and gracefully so that they are requested to speak in "kalimatun sawaa" (meeting point or common terms) not to distance from him (Ali Imran: 159).

The Prophet Muhammad set a good example to his wife about dealing gently with other people, including those from different religions. Once a Jew came to the Prophet by saying "al-saamu alayka" (peace upon you), and the Prophet replied, "al-salaamu alaykum" (peace upon you too). When 'A'isyah answered them with the same answer, "al-saamu alaykum" (woe upon you), the Prophet rebuked her and asked her to answer their greetings using a soft language that would not offend them. The Prophet's wife responded to him, "O Prophet, didn't they say: 'al-saamu alayka'?". To his wife, who seemed to still believe in her attitude, the Prophet answered by using a questioning tone, "Did you not hear my answer, 'A'isyah"? (Al-Sirjani, 2011b).

The Al-Qur'an also encourages Muslims to use terms that are not insensitive to other people even though the expression is true, for instance, the designation of "kaafir" (infidel). Although the al-Qur'an designates them as kafir (al-Tahrim:7 and al-Kaafirun:1-6), Yusuf al-Qardawi suggests not to use the term of the context of a plural nation. Instead, other terms like non-Muslim (ghayrul muslim) are used because the term kafir has many meanings. Alternatively, the term citizen is more neutral to denote adherents of other religions as a minority group in a 
Muslim majority country like Indonesia. Correspondingly, it is advised to use the term "humanitarian brotherhood" (ukhuwah insaaniyah) to designate citizens with different religions, because essentially, they are humans, creatures of the same God (al-Hujurat: 13) and from the same element "nafsun waahidah" (a single being) (al-Nisa': 1) (see also Qardawi, 2004).

\section{Ethics toward Fellow Muslims}

The Al-Qur'an states that Muslims are the best community because they carry out obligations and avoid prohibitions (Ali Imran: 110) (Al-Dimasqi, n.d.). Therefore, the Al-Qur'an commands Muslims to become uniting people (Al-Khauli, n.d.). A hadith stated by the Prophet emphasizes that the believers are brothers and sisters. In this case, if a Muslim hurts, the rest feel the pain. Therefore, the believers must not be cruel (zalim) to fellow Muslims; instead, they must help each other (AlKhauli, n.d.). Likewise, they essentially love each other (Al-Khauli, n.d.). A Muslim cannot be reckoned a perfect believer until they love the fellow believers as they love themselves (Al-Khauli, n.d.).

Correspondingly, a Prophet's hadith defines a true Muslim as "The person whom fellow Muslims are freed from his or her bad mouth and action." If a Muslim meets fellow Muslims, it is advisable to say salam (Islamic greeting) "assalamu'alaikum." This greeting is a supplication in the form of word and action, which means "may peace be upon you." Heaven is hailed as "daar alsalaam", or a home for peaceful people who act peacefully 
and spread peace to others. Therefore, it is not allowed for a Muslim to hurt fellow Muslims by calling anyone that has a different religious opinion, organization, and political orientation as kaafir (infidel), thaghut (devil), mushrik (polytheist), bid'ah/innovator (create something without precedence), heretic, cebong (tadpole), jancuk (insult), bajingan (crook), and other hate expressions that disrupt the unity among Indonesian Muslims.

\section{E. Conclusion}

In conclusion, several aspects have been discussed in this paper. Firstly, the paper discusses the conceptual structure of Islam, consisting of the trilogy of Islam, iman, and ihsan, that culminate in ihsan, tasawwuf, akhlaaq, and ethics. Secondly, in the context of religious lives and the coexistence with the adherents of other religions, Muslims essentially relates the theological truth onto religious ethics (the ethics of the Al-Qur'an), which combines three elements of ethics: God's, religious, and social ethics. The last two ethics should refer to God's affirmative ethics, such as His attributes of Most Merciful and Most Just. In this case, God has mercy on and treats humans justly. Likewise, it is essentially applied to humans' ethics in their relationship with God and fellow human beings. In addition, because God gives His blessing and loves human beings, humans actually serve sincerely to God. Meanwhile, in fulfilling their duties as caliphs, humans must act kindheartedly, promote brotherhood and harmony, help each other, and avoid hatred, as well as physical and nonphysical violence. 


\section{References}

Al-Attar, M. (2017). Meta-ethics: A quest for an epistemological basis of morality in classical Islamic thought. Journal of Islamic Ethics, 1(1-2), 29-50. https://doi. org/10.1163/24685542-12340003

Al-Dimasqi, M. J. al-Q. (n.d.). Mau'idah al-mukminiin, min ihyaa'i uluumiddiin. Maktabah al-Hidayah.

Al-Ghazali. (2001). Etika berkuasa: Nasihat-nasihat Imam alGhazali, trans. Arief B. Iskandar. Pustaka Hidayah.

Al-Jabbar. (n.d.). Sharhu usul al-khamsah. Maktabah Wahbah.

Al-Khatib, M. (2017). Ayat al-akhlaaq: Su'al Akhlaq 'inda almufassiriin. Journal of Islamic Ethics, 1(1-2), 83-121. https://doi.org/10.1163/24685542-12340005

Al-Khauli, M. A. al-A. (n.d.). Al-Adab al-Nawawi. Daar al-Fikr.

Al-Maududi, A. al-A. (n.d.). Mabaadi' al-Islam. Al-Maktabah alIslaami.

Al-Nafis, A. R. (2006). Al-shi'ah wa al-tashyyi' li ahli bayt. Maktabah Shuruuq al-Dawlah.

Al-Shahrashtani. (1961). Mu'assasah al-mukhtaar. TP.

Al-Sirjani, R. (2011a). Fann al-Ta'amul al-Nabawi Ma'a Ghayri al-Muslimiin (4th ed.). Cairo: Daar al-Kutub al-Mishriyah dan Aqlaam.

Al-Sirjani, R. (2011b). Mustaqbal al-nasaraa fii al-dawlah alIslamiyah. Dar al-Kutub al-Misiriyah.

Al-Wahhab, M. bin A. (1969). Kitaab al-tawhiid alladhi huwa haqqullah 'alaa al-'abdi. Daar al-'Arabi. 
Aristoteles. (2004). Sebuah kitab suci etika, Necomachean ethics, trans. Embun Kenyowati. Teraju.

Aristotle. (2008). 'Ilm al-Akhlaq ilaa nicomachean. Al-Hai'ah al-Mishriyah al-Amah li al-Kitab.

Azzam, A. al-W. (n.d.). Akhlaq al-Qur'an. Maktabah al-Nur.

Baydaba. (2004). Kalilah wa dimnah: Fabel-fabel allegoris, trans. Wasmukan. Pustaka Hidayah.

Bertens, K. (2011). Etika (11th ed.). Kanisius.

Bertens, K. (2017). Pengantar filsafat. Kanisius.

Bruinessen, M. van. (2015). Kitab kuning, pesantren dan tarekat (2nd ed.). Gading.

Chaney, C., \& Church, W. T. (2017). Islam in the 21st century: Can the Islamic belief system and the ethics of social work be reconciled? Journal of Religion \& Spirituality in Social Work: Social Thought, 36(1-2), 25-47. https:// doi.org/10.1080/15426432.2017.1311246

Donner, F. M. (2015). Muhammad dan umat beriman: Asal usul Islam, trans. Syafaatun al-Mirzanah. Gramedia.

El Fadl, K. A. (2017). Qur'anic ethics and Islamic law. Journal of Islamic Ethics, 1(1-2), 7-28. https://doi. org/10.1163/24685542-12340002

Fakhry, M. (1996). Etika dalam Islam, trans. Zakiyuddin Baydhawi. Pustaka Pelajar dan Pusat Studi Islam Muhammadiyah Surakarta.

Fathani, I. L. (2006). Al-Islaam diin al-salaam (2nd ed.). Ja'iyah al-Salaam bi Kulliyah al-Islaamiyah Jala.

Ghafran, C., \& Yasmin, S. (2020). Ethical governance: Insight from the Islamic perspective and an empirical enquiry. 
Journal of Business Ethics, 167(3), 513-533. https://doi. org/10.1007/s10551-019-04170-3

Halili, A. (2017). Mafhuum al-birru wa al-manzuumah alakhlaaqiyah al-Qur'aniyah: Al-bun'yah wa al-siyaaq. Journal of Islamic Ethics, 1(1-2), 122-157. https://doi. org/10.1163/24685542-12340006

Hammad, M. A. al-Q. H. (2010). Al-Haakimiyyah. Daar al-Saaqi.

Hanna, M. (2005). Menyongsongyang lain, membela pluralisme, trans. Guntur Romli. Jaringan Islam Liberal.

Haryatmoko. (2003). Etika politik dan kekuasaan. Bandung: Kompas.

Hazlitt, H. (2003). Dasar-dasar moralitas, terj. Cuk Ananta Wijaya. Pustaka Pelajar.

Husawi, A. al-R. bin A. al-J. S. (1999). Minhaj al-Qur'an alkarim: Tathbit al-Rasul wa takrimihi (2nd ed.). Daar alDzakhair/Muassasah al-Rayyan.

Ismail, F. (1999). Ideologi, hegemoni dan otoritas agama: Wacana ketegangan kreatif antara Islam dan Pancasila. Tiara Wacana.

Ismail, F. (2003). Ketegangan kreatif peradaban Islam: Idealisme versus realisme. Bakti Aksara Persada.

Izutsu, T. (1993). Etika beragama dalam al-Qur'an, trans. Mansorjdin Djoely. Pustaka Firdaus.

Izutsu, T. (1997). Relasi Tuhan dan manusia: Pendekatan semantik terhadap al-Qur'an, trans. Agus Fakhri Husein, Supriyanto Abdullah dan Amiruddin. Tiara Wacana.

Kant, I. (1785). Foundation of the Metaphysics of Morals.

Khan, M. A. M. (1997). Islam as an ethical tradition 
of international relations. Islam and ChristianMuslim Relations, 8(2), 177-192. https://doi. org/10.1080/09596419708721119

Liu, Y. (2011). The coordination function of Islamic ethics in transforming Islamic societies. Journal of Middle Eastern and Islamic Studies (in Asia), 5(3), 17-36. https://doi.or g/10.1080/19370679.2011.12023183

Madjid, N. (1994). Islam, Iman dan Ihsan sebagai trilogi ajaran Ilahi, in B. M. Rachman (ed.), Kontekstualisasi doktrin Islam dalam sejarah. Jakarta: Paramadina.

Madjid, N. (2008). Islam, doktrin dan peradaban (6th ed.). Paramadina.

Milkiyan, M. (2013). Jadaliyah al-diin wa al-akhlaaq. AlIntishaar al-Arabi.

Miskawaih, I. (2011). Tahdzib akhlaaq. Manshuraat al-Jamal.

Mpu Prapanca. (2018). Kakawin Negarakertagama, trans. Damaika Saktiani, Kartika Widya, Zakariya Pamuji Aminullah, Novi Marginingrum, dan Nedta Septi.

Mpu Tantular. (2019). Kakawin Sutasoma, trans. Dwi Woro Retno Mastuti dan Hasto Bramantyo. Komunitas Bambu.

Muslim, I. (2001). Sahih Muslim bi sharhi Imam Nawawi, mujallad al-awwal. Mu'assasah al-Mukhtaar.

Nashir, H. (2013). Islam syari'at: Reproduksi salafiyah ideologis di Indonesia. Mizan.

Qardawi, Y. (2004). Khithabunaa al-Islaami fi 'asri al-aulamah. Daar al-Shuruuq.

Quasem, M. A. (1975). Etika al-Ghazali, trans. J. Mahyudin. Pustaka. 
Rahmat, I. (2009). Arus baru Islam radikal: Transmisi revivalisme Islam Timur Tengah ke Indonesia. Erlangga.

Rahmat, J. (2006). Islam dan pluralisme: Akhlaq al-Qur'an menyikapi perbedaan. Serambi.

Raisuni, A. (2010). Al-kulliyaat al-asaasiyah li al-sharii'ah alIslaamiyah. Daar al-Amaan and Daar al-Salaam.

Reda, N. (2019). What is the Qur'an? A spiritually integrative perspective. Islam and Christian-Muslim Relations, 30(2), 127-148. https://doi.org/10.1080/09596410.2 019.1605104

Riswani, S. (2017). al-Darsu al-akhlaaqi li al-Qur'an: Qiraa'ah fi ba'di al-muqaarabaat al-hadiithah. Journal of Islamic Ethics, 1(1-2), 158-194. https://doi. org/10.1163/24685542-12340007

Safi, L. M. (2011). Religious freedom an interreligious relation in Islam: Reflections on da'wah and Qur'anic ethics. Journal The Review of Faith and International Affairs, 9(2), 11-16. https://doi.org/10.1080/15570274.2011. 571422

Shahrur, M. (1996). al-Islam wa al-Iman: Manzuumat alqiyaam. Al-Ahaali.

Shahrur, M. (2014). al-Diin wa al-Sultah: Qiraa'ah mu'aasirah li al-haakimiyah (3rd ed.). Daar al-Saaqi.

Shoroush, A. al-K. (2009a). Bast al-tajribah al-Nabawiyyah, trans, Ahmad al-Qabbanji. Daar al-Jadiid.

Shoroush, A. al-K. (2009b). Basth al-tajribati al-Nabawiyyah, trans. Ahmad al-Qobbanji. al-Intishar al-'Arabi. 
Siddiqui, A. (1997). Ethics in Islam: Key concepts and contemporary challenges. Journal of Moral Education, 26(4), 423-431. https://doi. org/10.1080/0305724970260403

Summa, M. A. (2004). Pluralisme agama menurut Al-Qur'an: Telaah akidah dan Syari'ah. Jakarta: Pustaka Firdaus.

Suseno, F. M. (2010). Etika sasar: Masalah-masalah pokok filsafat moral. Kanisius.

Taymiyah, I., \& Al-Wahhab, A. A. bin A. (1991). Majmu'atu altawhid, wa tashmalu 'alaa sittati wa 'ishriin risaalah. Daar al-Fikr.

Thaha, M. M. (2007). al-Risaalah al-Thaaniyah min al-Islam", fi (Nahwa Mashru' Mustaqbalay li al-Islam: Thalaathah min al-A'maal al-Asasiyyah li al-Mufakkiri al-Shahiid). Markaz Thaqafi al-'Arabi.

Umar, N. (2019). Jihad melawan religious hate speech. Quanta/ Kompas Gramedia.

Wahid, A. (2006). Islamku, Islam anda, Islam kita: Agama, masyarakat, negara, demokrasi. The Wahid Institute.

Wijaya, A. (2013). Satu Islam, ragam epistemologi: Dari epistemologi teosentrisme ke antroposentrisme. Pustaka Pelajar.

Wijaya, A. (2018). Dari membela Tuhan ke membela manusia: Kritik atas nalar agamaisasi kekerasan. Mizan.

Wijaya, A. (2019). Kontestasi merebut kebenaran Islam: Dari berislam secara teologis ke berislam secara humanis. IRCiSod. 
Yaqut, M. M. (2009). Nabiyyu al-rahmah. Daar al-Kharraz.

Zaqzuq, M. H. (1983). Muqaddimah fii 'Ilmi al-akhlaaq. Daar al-Qalam. 